initial and final $s$ were quite lost, and the action of the mutes, $c, t$, was almost nil.

The invention is highly interesting, the effects at present produced are sometimes startling (as in cries, coughs, laughter, music), the philosophy of the process (taking a permanent impression of a very complex compound vibration, and using it as a mould to reproduce that vibration) is exceedingly attractive, but at present the instrument-at least that one which I saw, differing in many respects from the one described by Prof. Mayer-has not risen beyond a lecture illustration or a philosophical toy.

April $\mathfrak{1} 3$

\section{Phoneidoscopic Representation of Vowels and Diphthongs}

PERHAPS your correspondent, Mr. Sedley Taylor, would kindly test with his phoneidoscope the propriety of calling the English combinations $e a, a e, o e$, ie diphthongs, and the simple vowel $I$, as pronounced in the personal pronoun, a simple sound. Perhaps also the English $\vec{a}$ (as in " name") may be regarded as a diphthong. In Otto's German Gramanar, the German cosabinations $a e, o e, u e$, are classed as modified vowels. I fancy oe is a diphthong, though in rapid speech it becomes more like the simple sound we.

I. H. BLAKESLEY

Linden, Hamover, April I

The Acoustical Properties of Soap Films.

IN connection with the interesting results recently obtained by $\mathrm{Mr}$. Sedley Taylor upon the acoustic properties of soapfilms, as exhibited in the simple and beautiful instrument which he has termed the Phoneidoscope, I should like to call attention to the following passage published in 1873 by Prof. E. Mach, of Pragne, in his Optisch-Akustische Versuche:-

"Bei dieser Gelegenheit kam erwähnt werlen, dass"die Plateau'schen Flüssigkeitshäutchen sich vorzüglich zum Studium der Membranschwingungen eignen. Eine solche Fliissigkeit:haut vor eine tönende Pfeife gebracht zeigt meist mehrere Bäuche. Ein Lichtpunkt, der sich in der Membran spiegelt, gibt mehrere glanzende geschlossene Curven."

After some remarks on the low tones to which these films vibrate, and on their vibrations to the upper partial tones, the author passes on to another subject with the remark:- "I Ich erwähne diese Experimente, weil sie vielleicht, weiter verfolgt, zur Beantwortung mancher Fragen uiber Membranschwingungen beitragen können."

There is no mention, however, of the rotating pairs of coloured vortices noticed by Mr. Sedley Taylor. Brewster appears to have observed similar phenomena (see Edin. Trans., vol. xxiv, "On Colours of Soap Bubbles," \&c.) as the result of directed currents of air upon films. I have found that the vortices are also produced when a small lightly vibrating tuningfork, having its prongs previously wetted with soap solution, is made to touch a flat soap film produced in the ordinary manner.

University College, Bristol, April 5 SILANUS P. THOMPSON

\section{Cumulative Temperature}

THE idea of a clock with an uncompensated pendulum for temperature integration referred to by Mr. Cooke (NATURE, vol. xvii. p. $3^{23}$ and p. 448) has probably occurred to many persons, and was proposed by me in 1840 ; I found, however, that it was not new then. Forbes says in his Report on Meteorology (Brit. Assoc. Report, 1832, p. 213) :-“A mechanical mode of taking the mean of an infinite number of temperatures has been proposed by M. Grassman, by observing the change of rate caused by the influence of temperature upon the uncompensated pendulum of a clock (Poggendorff, 1825). The idea is a good one, but was proposed long ago by Ur. Brewster ('Edinburgh Encyclopædia,' art. Atmospheric Clock)." The chief merit in this matter will belong to the person who puts the idea into a working form which can be proved capable of giving accurate results.

April 9

\section{The Southern Drought}

IN response to your question appended to my letter in the last number of NATURE, I am able to give you the time of the last great drought in the Gilbert Islands. In 1870 I visited these and several other islands in the Sonth Pacific (an ac count of my cruise appeared in Dr. Petermanu's Mittheilungen for June, I871), and at that time there was a very general dronght. I was among the uGilbert Islands during October, and found that no rain had fallen there for several months. The cocoa-nut and pandanus-trees, upon which the people almost entirely depend for food, were very much dried up, and the fruit upon them were small, both in quantity and in size. 'This drought continued for two years after my visit, and the famine became so severe that many of the people were starved to death. Had it not been for the fis they procured, it is doubtrul whether any of them would have survived, for the cocoa-nut and pandanustrees ceased to yield fruit, and the poor people were obliged to chew the roots of the trees.

Since that time I have heard of another season during which there was little rain, in consequence of which there was comparative scarcity, but this was not to be compared with the great drought of $1870-1872$.

I regret to say no long-continued observations on the rainfall have been made in Samoa. My own time was so fully occupied with other matters, during my residence there, that I neglected this one. As the droughts there have not been great enough to cause anything like distress, the periods of their occurrence have, unfortunately, not been recorded. S. J. WVHTMLE:

Blackheath, April 5

\section{Research in Libraries}

BEFORE this "voice from Australia" can reach Lomlon, I hope that some steps will have been taken towards carying out Dr. Mallet's valuable suggestion (NATURE, vol, xvi. p. 457) so far as regards the British Minseum and other leading European libraries.

The benefit of the proposed arrangement would, I am sure, be felt in Australia as much as in America. Anybody living here, in the North of Queensland, who may wish to consult a scientific book mutst take a sea voyage of 700 or 1,100 miles at a cost of $\mathbf{1 5 l}$. or $20 \mathrm{l}$. in money and at least a fortuight or three weeks in time. It may happen that one has a busy friend in the library city who will tndertale the search through goodnature, but most people would prefer to employ a competent man who would do so as a matter of basiness.

Should the trustees or directors of the great libraries hesitate (and they may) to accept the responsibility of recommending searchers, probably it would answer nearly as: well if the searchers were to advertise references to well-known scientific or literary men. Perhaps a hint might be taken from the Keroister House in Edinburgh. Titles to land in Scotland require registration for their completion. A purchaser, to satisfy himself that the seller has not previously alienated or burdened the subjects, has to overhanl the books of the register. This is done for him as a rule by professional searcher:, some of whom are official and some mofficial. The system has worked admirably for some centuries I believe. Any Scotch lawyer could explain its details.

The subdivision of labour suggested by Dr. Mallet woutd enable a much higher use to be made of the system than the mere hunting-up of references. For example, if there were a searcher in Paris-a well-read geologist-to whom I conld intrust an order for "any references in French geographical works bearing on the date of the erosion of the terrace between the Queensland coast range and the Pacific," or some such information, what possibilities would open ont to the divellers in distant isles, nay, even to the comparatively privileged inhabitants of London itself? $\quad$ ROBERT L. JACK

Geological Survey Office, Townsville, Queensland, Jan. I4

\section{Mimicry in Birds}

WITH reference to the correspondence on this subject which has recently apeared in NATURE, may I add the following instance, which has fallen under my own observation?-

On the coast of Kent is a tract of land protected from the sea by an embankment of shingle, and known as the "Reculver Marsh.” It is frequented by skylarks and ring-plovers. Almost all these larks have incorporated the well-known alarm note of the plovers into their song. With such distinctness is this double note brought in, that the first time I heard it I could with difficulty convince myself that it was not uttered by AEgialitis hiaticula. 